\title{
Political ecologies of extinction: from endpoint to inflection-point. Introduction to the Special Section
}

\author{
Bram Büscher ${ }^{1}$ \\ Wageningen University, The Netherlands \\ Stellenbosch Institute for Advanced Study, Republic of South Africa \\ University of Johannesburg, Republic of South Africa
}

\begin{abstract}
Amidst the many socio-ecological crises facing the world today, the biodiversity crisis is considered one of the most foundational. Many scientists believe we have entered yet another mass extinction event in the history of the planet, though the first one triggered by the impacts of the combined, uneven actions of one species. This introductory article frames this crisis through political ecology and explores what political ecologies of extinction could look like and focus on in the $21^{\text {st }}$ century. Building on emerging literatures and the contributions to a Special Section, it concurs that extinction is much more than the endpoint of a long and rocky road of the decline of a species. It is a dynamic, historical process that conjoins political, geographical, socio-ecological, and other factors. Most of all, a political ecology of extinction highlights the intertwined forces of political economy, power and ecology within which I argue a special focus should be on how biological diversity and our understanding of it has changed over time, especially the last two centuries. The capitalist intensification of pressures on biological diversity combined with changing perceptions of the value of diversity during this time have led to a moment where extinction moves decisively from a biological endpoint to a political inflection-point. How to relate these two 'points' to historical and contemporary, local and global forces of political economy and power is central to political ecologies of extinction, as exemplified by the articles in this Special Section.
\end{abstract}

Keywords: extinction, political ecology, biodiversity, capitalism, power

\section{Résumé}

La crise de la biodiversité est considérée comme fondamentale. De nombreux scientifiques pensent que nous sommes entrés dans un nouvel événement d'extinction massive, le premier déclenché par les impacts humains. Cet article d'introduction explore les écologies politiques de l'extinction au 21ème siècle. En m'appuyant sur les articles de cette section, je soutiens que l'extinction est un processus dynamique et historique qui associe des facteurs politiques, géographiques, socio-écologiques et autres. Par-dessus tout, il entrelace l'économie politique, le pouvoir et l'écologie. L'intensification capitaliste des pressions sur la diversité biologique et notre compréhension de celleci ont changé, surtout au cours des deux derniers siècles. L'évolution des perceptions de la valeur de la biodiversité signifie que l'extinction implique un point d'inflexion politique, et pas seulement un point final biologique. Les écologies politiques de l'extinction relient ces deux "points" aux forces et aux pouvoirs locaux et mondiaux.

Mots clés: extinction, écologie politique, biodiversité, capitalisme, pouvoir

\section{Resumen}

La crisis de la biodiversidad se considera fundacional. Muchos científicos creen que hemos entrado en otro evento de extinción masiva, el primero provocado por el impacto humano. Este artículo introductorio explora las ecologías políticas de la extinción en el siglo XXI. Basándome en los artículos de la Sección Especial, sostengo que la extinción es un proceso dinámico e histórico que conjuga factores políticos, geográficos, socioecológicos y otros. Sobre todo, entrelaza la economía política, el poder y la ecología. La intensificación capitalista de las presiones

\footnotetext{
${ }^{1}$ Prof. Bram Büscher, Professor and Chair, Sociology of Development and Change, Wageningen University, The Netherlands; Fellow, Stellenbosch Institute for Advanced Study, Wallenberg Research Centre at Stellenbosch University, South Africa; Visiting Professor, Department of Geography, Environmental Management and Energy Studies, University of Johannesburg, South Africa. Email: bram.buscher "at" wur.nl. Acknowledgements: thanks to the participants at the Crisis Conservation workshop held from 5-9 October 2020, to Simon Batterbury, Rob Fletcher, Stasja Koot and Lerato Thakholi for helpful comments and suggestions on a first version of this article. Special thanks to Ananda Siddhartha for efficiently managing and steering the entire submission and peer-review process. The workshop and the research for this article were made possible by an NWO-VIDI grant (nr. 425-14-001). This is the Introduction to Bram Büscher (ed.). 2021. "Political ecologies of extinction", Special Section of the Journal of Political Ecology 28: 696-888.
} 
sobre la diversidad biológica y nuestra comprensión de la misma ha cambiado, especialmente en los dos últimos siglos. Los cambios en la percepción del valor de la biodiversidad hacen que la extinción implique un punto de inflexión político, no sólo un punto final biológico. Las ecologías políticas de la extinción relacionan estos dos "puntos" con las fuerzas locales y globales, y con el poder.

Palabras clave: extinción, ecología política, biodiversidad, capitalismo, poder

\section{Introduction: from endpoint to inflection-point}

There is nothing straightforward about extinction. Its dominant meaning as the endpoint of the life of a species may sound relatively uncomplicated, but is far from it either in practice or in theory. Most practically, socalled 'rediscoverers' seek to show that many proclaimed extinctions may be wrong or based on faulty assumptions (Watson and Davis, 2017). But defining, disproving, or finding proof for a 'species endpoint' is only scratching the surface when it comes to thinking about extinction. As Rose and colleagues (2017: 2) argue, "there is no singular phenomenon of extinction; rather, extinction is experienced, resisted, measured, enunciated, performed and narrated in a variety of ways to which we must attend." Emerging literatures are doing just this.

For one, these literatures note that extinctions are a hard thing to swallow in more ways than we can often imagine. Even thinking and writing about them is difficult. Jones, Rigby and Williams (2020: 388) start their article on the topic by saying "we do not want to be here" and that their "thinking and writing" about extinction comes with "the deepest sadness, anger, and bewilderment." Acute-yet-enigmatic senses of loss, absence and grief accompany thinking and writing about extinction, and this goes for most if not all who try - across disciplinary boundaries, within or beyond academia (Van Dooren, 2014; Barnosky, 2014; Rose et al, 2017). This is also the reason why McCorristine and Adams (2020: 101) argue that there is a "spectral quality of debates about extinction." At the same time, according to Jørgensen (2019), these emotions also render any efforts to prevent or undo (spatial and other) extinctions extremely complex. All this means that the idea of extinction as endpoint is rather shallow and unsatisfactory, even if its material realities should not be eschewed in our analyses.

This is a point also made by Theriault et al. (2020: 899). They argue that a "framing of extinction-asspecies-death" is worrying but also that it "emerges from a societal context in which life forms are divided into discrete categories, their interactions reduced to 'behavior', and moral agency denied, except in the case of a particular ideal of homo sapiens rooted in post-Enlightenment Euro-American thought." They, and others, argue that non-western, Indigenous ways of understanding the 'destruction of life forms' relates to 'broken protocols' amongst all living beings and that the focus must be on 'living protocols' that remake and reinvent relations between all forms of life (see also Mitchell, 2016; Rose et al., 2017). From these perspectives, extinction moves from the universal to the 'pluriversal', with specific attention to contingent and discordant ways of living and dying across actor-networks, geographies, temporalities and geo-biophysical formations (Garlick and Symons, 2020). Even the latter, like glaciers, can be said to go 'geologically extinct' (Schmidt, 2021).

Because "extinction is a process and moment of loss that compels thought about the moral relationships among humans, nonhuman species, and habitats, as well as among social groups with varying degrees of power and autonomy" (Sodikoff, 2012: 10), its study and contemplation lends itself well to more-than-human, multispecies, post-human and related social-theoretical approaches that emphasize entanglements, relationalities and plurality (see, e.g., Rose et al, 2017; Salazar Parreñas, 2018; Guasco, 2020; Garlick and Symons, 2020; Bersaglio and Margulies, 2021). These analyses also aim to move beyond simplistic understandings of extinction as singular events, to emphasize extinction as comprising processes-within-context over time, and how these relate to different subjectivities and positionalities. This field of 'extinction studies', most prominently based in environmental humanities but with important links to geography, anthropology and other social science disciplines, is small but growing rapidly (see Van Dooren, 2017: 5).

To a good degree, political ecology is central to these emergent literatures on extinction. After all, as Greenberg and Park noted in JPE in 1994, political ecology is the "historical outgrowth of the central questions asked by the social sciences about the relations between human society, viewed in its bio-cultural-political complexity, and a significantly humanized nature. It develops the common ground where various disciplines intersect" (1994: 1). This common ground across divergent approaches and theoretical emphases demonstrates why political ecology is a critically important field in understanding and confronting the multiple, overlapping socio-ecological crises that beset the world today (Bryant, 2015; Harcourt and Nelson, 2015). As argued earlier (Büscher, 2021), I believe that that across divergent approaches and theoretical differences, one element of this 
common ground is the need to understand, confront and transcend the capitalist political economy, something that is clearly visible in the emerging literatures on extinction (Theriault et al, 2020; Bersaglio and Margulies, 2020).

However, the links among political economy, power and extinction are not nearly as well developed as other aspects in these literatures. If indeed the current mass extinction event is the outcome of the uneven historical development of capitalism, then surely this should have triggered more heated debates and scientific research. To date, however, only a few serious attempts at addressing and unravelling this connection have been made (Dawson, 2016; McBrien, 2016). ${ }^{2}$ Many focus on the 'story of conservation' in response to extinction threats, like Adams' (2004) foundational work, while others show how these have recently turned more violent (Marijnen and Verweijen, 2016; Büscher and Ramutsindela, 2016; Duffy et al., 2019). Ashley Dawson (2016, backflap) has been most explicit, arguing that "extinction cannot be understood in isolation from a critique of our economic system." His short book broke new ground by exploring this connection but it lacks empirical research and broader theoretical engagement. Moreover, and despite his attention to rewilding, Dawson pays little attention to different dimensions of unevenness in the political economy of biological diversity more broadly, particularly how actual species dynamics may go up or down for myriad reasons under different political economic contexts.

Taking seriously that extinction is more than an endpoint. That it relates to uneven dynamics around biological diversity and that there is a special relationship with the political economy of capitalism, all corroborate the need for elaborating political ecologies of extinction. Indeed, extinction, in this understanding, becomes a sign of the times we are in: it moves from an ecological endpoint to a political economic inflection-point. The next section elaborates this in more detail, after which I will provide some suggestions how this can be used to develop political ecologies of extinction more generally and how the contributions to the Special Section contribute to this.

\section{Extinction as inflection-point}

Extinction as an inflection-point works as a prism: it centrally illuminates diverse yet overlapping emergencies, what some refer to as the 'era of concatenated global crises' (Biggs et al., 2011). It does so because extinction is, together with the climate, centrally connected to the very functioning of the earth system and its dependence on - and ability to support - a diversity of life (Hannah, 2021: 122-123). In other words, extinction clarifies the enormity and severity of the stakes involved, something that is now also forcefully argued by 'earth system governance' theorists: "the unprecedented heating of our planet or species mass extinction are issues fundamentally important for survival. The traditional framing of these risks as 'environmental' problems has consistently downplayed the issue from an existential threat to something that is a more ordinary policy challenge" (Biermann, 2021: 70). Biermann and many earth system governance theorists, however, do not connect this to the political economy of capitalism, which again leaves an important agenda open for political ecologists.

What I want to suggest here is that extinction as inflection-point is one of the core 'earth system' counterpoints to the political economic inflection-point and prism that is capital. These are, and have long been, dialectically integrated, yet their specific relations have developed over time in ways that demand urgent research and conceptualization. This starts from the history of the 'discovery' of extinction by George Cuvier in the early $19^{\text {th }}$ century, as alluded to by Wrigley (2021). This was the time when the earth system was frantically mapped and studied and when it dawned on western savants that the earth was much older than previously presumed. In the $17^{\text {th }}$ century, "most people in the Western world, whether religious or not, took it for granted that humanity is almost the same age as the Earth" (Rudwick, 2014: 9). It was hardly imaginable that life was dynamic, changing and long-lived rather than static and divinely preordained. Only with mounting geological evidence did it become gradually clearer that the Earth had a very long history, full of diverse forms of life. The acceptance of extinction was critical in this process. As Rudwick summarizes:

The single most striking feature of this almost unimaginably lengthy history of the Earth - and not just because we ourselves are among its products - was the history of life. That life had had any true history, rather than remaining more or less the same all along, had been utterly uncertain until Cuvier and others in the early $19^{\text {th }}$ century demonstrated the reality of extinction, which showed that the life of earlier periods has been distinctly different from that of the present world. (Rudwick, 2014: 296).

\footnotetext{
${ }^{2}$ This excludes earlier catastrophist thinkers whe have, generally, not connected critically to power and political economy.
} 
The demonstration of extinction triggered massive scientific and popular interest in the origins and evolution of life, including humans, which famously led to the Darwinian revolution and other influential scientific and social developments. At the same time, the way extinction was recognized and subsequently taken up in emerging Western discussions and imaginaries was closely tied to the imperial, capitalist political economy then in full upswing. In his book Catastrophic Thinking, historian David Sepkoski traces the development of thinking about extinction from the Victorian age to contemporary times. He argues that in Victorian times extinction was seen as "(1) slow and gradual, (2) reciprocally balanced by the replenishment of new species, and (3) in some sense progressive. That is, by reflecting the 'fair' outcome of natural competition, it contributed to the robustness of living ecosystems by weeding out 'unfit' individuals or species" (Sepkoski, 2020: 9). In short, extinction was not viewed negatively per se, but as part of a broader, progressive force that saw some individuals or species inevitably lose out vis-à-vis others. This was also, infamously, used to justify imperialism and the mass murder and enslavement of many Indigenous and other peoples around the world (Powell, 2016; Theriault et al., 2020).

Sepkoski argues that this view has changed drastically: according to him biological and cultural diversity are now viewed as innately good. A new understanding of extinction emerged, "in which (1) extinction is seen as a potentially catastrophic and irreversible process, (2) extinction is characterized explicitly in terms of its effect on diversity, and (3) survival is no longer conceptualized as 'fair game' in which extinction penalizes only those individuals and species who 'deserve it"' (Sepkoski, 2020: 10). Sepkoski shows that this transformation was highly complex and that the two understandings have been challenged in myriad ways. In building his narrative, he focuses on the cultural value of diversity in 'thinking catastrophically' about extinction. Much less explicit for him is how this relates to political-economic transformations and changing ideas about order, knowledge and power.

Nonetheless, Sepkoski's work shows that extinction was an important inflection point in the $19^{\text {th }}$ century and that it has again become so more recently, though based on different conceptualizations and understandings (see Barrow, 2009). Given this transformation it is, again, not illogical to see why especially post/more-than human theories are so popular: precisely because extinction is an inflection-point rather than an endpoint, and because it highlights critically important political needs to acknowledge deep historical wrongs and to find different ways forward in the relation between humans and the rest of nature, beyond imperialism, colonialism and capitalism.

Having said this, a focus on extinction as inflection-point can never completely transcend or disregard extinction as (material, biological) endpoint. After all, the latter is why many scientists now believe we have entered the sixth extinction event in the history of the planet (Barnosky et al., 2011; Tucket et al., 2018). More importantly, the material realities of extinction are frightening. If we take the conclusion of the influential report of the Intergovernmental Science-Policy Platform on Biodiversity and Ecosystem Services (IPBES, 2019) at face value, then the mere possibility that over a million species are at risk of extinction alone requires drastic and rapid societal and economic transformation. This is why, combined with the climate crisis, new social movements have declared an emergency and call on citizens to rebel in order to counter the crisis (Extinction Rebellion, 2019).

Hence, I return to my earlier point that extinction and the biodiversity crisis, together with the climate crisis (IPBES-IPCC, 2021), are the earth system counterpoints to the broader crises of capital in the $21^{\text {st }}$ century. At the same time, climate and extinction differ across many dimensions, including precisely how they relate to broader dynamics of political economy and power. For one, as Turnhout and Purvis (2021: 11) show, scientists have long tried to find a simple metric that can elucidate the biodiversity crisis in the way $\mathrm{CO}_{2}$ functions for climate change. Extinction rates are often believed to be this metric. But given that extinction is "hard to demonstrate" and since it is the very final stage in an often long and rocky downward process, "action will often come too late and the target will not be very responsive to policy interventions." Turnhout and Purvis conclude that "choosing species extinction rate as the focus for a single biodiversity target therefore seems unwise." This further emphasises the need to move the debate from biological endpoints to a political inflection point that combines the physical, ecological and material with the socio-cultural, political-economic and an other-than-western epistemological. Political ecology is well positioned to not just push but also lead these debates.

\section{Political ecologies of extinction in times of exception and enmity}

Clearly, many literatures in political ecology and related fields already touch on the concerns outlined above. But as I argue, in relation to histories and contemporary politics and political economy of extinction there is still much to be done. Indeed, there is such a rich field of research to be set up around the question of extinction that this Special Section only scratches the surface. Important areas for further research that the articles in this Special Section point at, amongst others, are the connections between extraction and conservation in relation to 
extinction (Le Billon, 2021; Nel, 2021; Meszaros Martin and Pedraza, 2021), the relation between new digital technologies and studying, knowing and understanding extinction processes (Kiggel, 2021), the relations between extinction, de-extinction and a broader cryo-politics of life (Wrigley, 2021), the relation between psycho-analytic dynamics and extinction (Koot, 2021), how biopower affects extinction and responses to it (Thakholi, 2021) and how extinction fears can in fact be profitable and conducive to, rather than an indictment of, contemporary capitalism (Büscher, 2021).

More generally, as Deutsch (2021) highlights, the links between extinction and contemporary politics of authoritarianism need urgent further investigation. ${ }^{3}$ Clearly, this is a broader issue that intersects with many of the aforementioned topics and is already an important subject within political ecology (Neimark et al., 2019). Yet, authoritarian currents are but one element of a broader political climate in the $21^{\text {st }}$ century characterized by what Achille Mbembe (2019) refers to as the new 'politics of enmity' that is leading to a multiplication of antagonistic exceptions and exceptional circumstances. This politics of enmity, the seeking of separation and new forms of apartheid, is not merely detrimental to democracy, he argues, but creates a necropolitics that builds "new and unique forms of social existence in which vast populations are subjected to living conditions that confer upon them the status of the living dead" (Mbembe, 2019: 92). Death and terror, in other words, become caught in the tensions between biopolitical and necropolitical intensifications whereby "death itself increasingly tends to become spectral" (Mbembe, 2019: 38).

Building on extinction literatures, however, it seems critically important to extend Mbembe's analysis beyond 'forms of social existence' to 'new forms of socioecological existence' that connect the material-spectral death worlds of humans to those of nonhumans, and to further theorize their connections and intersections. To further this process, the Special Section places special emphasis on understanding and developing political ecologies in times of exception and enmity.

For example, and following the severity of the global biodiversity crisis, authors highlight how we are seeing an increasing number of high-pressure situations around the world where urgent action is required to safeguard important species or ecosystems from extinction. These disparate situations seem to be the complex outcome of a generic 'intensification of pressures' emanating from the capitalist political economy more generally, combined with a recent surge in large-scale resource extraction and wildlife crime, more specifically (Muradian et al., 2012). These forces have in turn elicited new types of conservation responses, leading to myriad 'spaces of exception' where violence, illegality and uncertainty drastically alter environmental governance.

This dynamic has stimulated a rapidly growing and dynamic literature in political ecology on the militarization of conservation and 'green violence' more generally (Lunstrum, 2014; Duffy et al., 2015; Marijnen and Verweijen, 2016; Büscher and Ramutsindela, 2016; Büscher and Fletcher, 2018; Duffy et al., 2019; Massé, 2019; Ramutsindela et al., 2022). The Special Section builds on this literature by further developing the links between forms of exceptional, violent conservation action and how they are connected to broader dynamics around biological diversity and extinction within the contemporary political climate of enmity, as conceptualized by Mbembe (2019) and others (see Le Billon and Duffy, 2018).

At the same time and conversely, we need to direct the broader spectral necropolitics of enmity and exception back to material geographies and histories of extinction and actual, lived human-nonhuman interactions in order to understand how broader forms of power and political economy resonate differently and unevenly across time and space. This means we need to connect the 'spectral' qualities of extinction debates (McCorrestine and Adams, 2020) to the more mundane, every day and material aspects of extinction processes. This requires asking how and why certain discourses of loss, absence and the possibilities of (preventing) extinction are connected to structures of power in particular places, which can often place conservation and other 'against extinction' (Adams, 2004) actions in a very different light.

To give one illustration, Jones et al. (2020) may certainly be right that successful action to prevent extinction means that there "is a form of hope stemming from the fact that complete extinction of the species will not happen. That is why preventing extinction is so important. It keeps possibility alive" (Jones et al., 2020: 393). At the same time, this Special Section argues we need to continuously ask precisely how extinction is prevented,

\footnotetext{
${ }^{3}$ For the climate crisis, some important inroads have been made here, see, for example, Malm and the Zetkin collective (2021).
} 
and what the power dynamics are behind this. ${ }^{4}$ The articles by Koot, Thakholi and Nel, for example, show that the drive to prevent the extinction of the rhino in South Africa may bring hope to some, but also despair and misery to many others, while the article by Büscher adds that, in this process, privately managed rhinos have actually increased in number rather than declined, despite the drastic discourses on the immanence of the extinction of the species. In sum, therefore: it remains critical to return continuously to the complex questions of power and political economy behind extinction and extinction discourses, imaginations, and related spectral politics.

\section{The contributions}

The articles in this Special Section all address different aspects of the extinction crisis in times of exception and enmity. Special emphasis is placed, inter alia, on the links between extinction, conservation and extraction, the way different conservation spaces (such as the Mata Atlantica in Brazil or the Kruger National Park in South Africa) experience more militant forms of conservation against the threats of poaching and extinction, the ways in which power and knowledge intersect to frame extinction, enmity and exception, the relationship between tourism and extinction, and new developments around de-extinction. All articles share a focus on analysing these topics with explicit reference to a broader political economic context of enmity that creates exceptions and crises, and therefore result in highly dynamic and swiftly changing political ecologies.

Lerato Thakholi (2021), in her article on the biopolitics of private conservation in South Africa, focuses on the responses to rhino poaching, many of which are driven by the desire to halt the extinction of the species. Employing a biopolitical lens, she brings into focus how power works in valuing different types of lives differently, in the quest to avoid extinction. In particular, she illuminates the plight of black conservation laborers and how their and also poachers' lives are less valued in practice than rhino lives. This is because active engagement to save rhino is juxtaposed against active non-intervention into the lives of black laborers. She also shows that there is a contradiction in how biopolitics works out across rhinos and laborers, namely that every individual rhino is deemed important for the health of the population, while every individual laborer should just be happy to have some income at all, given how the (surplus) population of potential labor is very large and of little concern to conservation.

Hannah Meszaros Martin and Oscar Pedraza (2021) focus our attention on the highly contradictory political economic situation in Colombia. Here, on the one hand, the conservation of endangered biodiversity is used to create a securitized corridor to control large tracts of land and monitor it for illegal activity, especially coca production. On the other hand, so argue Meszaros Martin and Pedraza, this conservation is a "form of necropolitics" as it also enables its opposite, namely large-scale development projects focused on coal mining and other forms of extraction. Coal, coca and conservation intersect in the Colombian political economic "context of the peace accords" (p. 722) to further intensify both environmental protection and destruction, with extinction caught in the middle. The extinction of certain plants (coca) is actively sought while the promotion of its supposed opposite, a form of conservation that, ironically, also enables coal mining, creates the extinction of certain forms of rural life.

Adrian Nel (2021) focuses on the South African province of KwaZulu Natal to show how neoliberal conservation strategies in the region have been extended through a focus on a 'biodiversity economy.' This economic framing, writes Nel, is supposed to further biodiversity conservation, safeguard targeted species such as the rhino against extinction, and provide jobs for marginalized rural residents. The overall result, however, seems very disappointing and hardly worth the massive effort put into developing the biodiversity economy. Indeed, the costs of the intervention he focuses on in the article seem excessive, and local struggles and enmity have intensified. Nel calls this a "pyrrhic strategy", where the costs of biodiversity conservation are not at all proportionate to its gains. In fact, he argues that the opposite results: the 'hegemonic' biodiversity framing, akin to a biopolitical mode of governance that Thakholi (2021) also identifies, creates "spaces of exception and sacrifice zones" (p. 754) that fuel further enmity.

Bram Büscher (2021) provides an overview of extinction dynamics in Africa, showing that although the general picture for wildlife preservation across the continent is rather negative, it is also uneven. In some regions, charismatic wildlife species have actually seen a numerical increase over the last decades due to the commodification of public and, especially, private forms of conservation and associated industries like wildlife

\footnotetext{
${ }^{4}$ In the process, different forms of power are at play, as laid out well by Svarstad et al. (2018) in this journal (see also Cavanagh, 2018).
} 
tourism. General species decline, and pockets of species growth, are part of broader political economic dynamics around the continent and how these impact conservation and wildlife. While according to Büscher the "intensification of uneven wildlife geographies in Africa" (p. 762) may not necessarily lead to dire predictions of the imminent extinction of certain charismatic wildlife species, he argues it may lead to something worse: the obscene profiteering from the overall decline of wildlife across the continent by those actors best able to capture and exploit remaining abundant pockets of wildlife.

Charlotte Wrigley (2021) presents a detailed study of wooly mammoth hunting in Siberia to highlight two important ways in which extinct animals and their frozen remains become part of broader political economies. The first is through their tusks, which are sold to markets in China and elsewhere for ornamental use. Here, extinct animal remains become part of a complicated, existing political economy of ivory that links with extinction fears of the mammoth's modern-day relatives. The second is through the selling of their genetic material to explore possibilities of mammoth de-extinction. Here, the mammoth becomes part of a political economy that has the potential reconstitution of life as we know it as its ultimate target. This, Wrigley argues, is not just the potential return of the mammoth as a living creature but, more profoundly, as "a tool through which to extend mastery and control over life" more generally (p. 795). Wrigley joins others to formulate a severe critique of this long-standing delusion of control and, in fact, concludes that what is really at stake in mammoth de-extinction is the possibility of human extinction and anxieties to prevent this.

Stasja Koot (2021) introduces the term 'environmentourism' to understand how tourism activities get (re)configured around their (potential) impact on the environment, in this case the conservation of rhino. Focusing on the rhino-poaching crisis in Southern Africa, Koot zooms in on how wealthy tourists are enabled to become part of activities to 'save the rhino' from extinction, and so experience the thrill of being at the forefront of conservation. This is a special thrill, one that oscillates between the enjoyment of doing something 'good' for an animal, while also enjoying the fact that one is part of a darker sort of activity, namely dealing with animals "at the brink of extinction" (p. 806). Koot employs the psychoanalytic term jouissance to denote how this doubleedged type of enjoyment taps "into fantasies of the white savior of African nature, and show how exorbitant luxury goes hand in hand with feelings of disgust and horror about poached rhinos" (p. 807).

Sierra Deutsch (2021) takes us to Brazil, arguably the most biodiverse country in the world as well as a key battleground in the global extinction crisis, to explain how environmental protection is impacted by contemporary Brazilian politics and political economy. Situated within a broader analysis of neoliberal authoritarianism, she focuses on Jair Bolsonaro's regime and how it has been undermining and dismantling environmental protection since he came to power in 2018. Cutting through the firehouse strategy of setting so many fires that people get distracted, she shows in detail how the Bolsonaro regime uses particular strategies to undermine environmental protection in order to stimulate further opportunities for capital accumulation. The Brazilian political economy, Deutsch argues, becomes embedded in systemic enmity and forms of exception, which in turn worsens our chance to meaningfully challenge the extinction crisis.

Thomas Kiggell (2021) also looks at Brazil but focuses on the use of new technologies in the monitoring of wildlife for conservation in the Atlantic Forest. He shows that, despite Bolsonaro's undermining of environmental efforts, much research on wildlife and conservation still takes place in Brazil, including the collection of ever-more quantities of data in order to monitor wildlife movements and dynamics. This enhances the possibilities for a more intense biopolitical governance of conservation, with several significant effects, as Kiggell shows. One of these is the often-greater distancing from local field realities above and beyond data-driven interactions, while another is how this distance could translate into arguments for more coercive conservation measures. These concerns become even more real with the extinction crisis, which in the fragmented Atlantic Forest biome takes on a strong form of defaunation. In a sense, then, Kiggell argues, this could become a biopolitics of 'monitoring extinction' itself.

Finally, Philippe Le Billon (2021) offers a combined analysis of conservation and extraction and argues that these seemingly opposing processes have remarkably similar conceptions of nature and biodiversity. Building on case studies in Brazil and in South Africa, he argues that "by fixing some of the crises of extraction, conservation enables its reproduction, or in other words helps to sustain extraction" (p. 872), which in turn creates spaces of "double exception." Through this term, Le Billon helps us to understand the complex interconnections between conservation and extraction in practice and how they generally support broader processes of capital accumulation rather than challenge these in any fundamental way. Indeed, both processes can, in tandem, have further negative impacts on communities, creating spaces of enmity above and beyond spaces of 'double exception.' 


\section{Bibliography}

Adams, W.M. 2004. Against extinction: the story of conservation. Earthscan.

Barnosky, A., N. Matzke, S. Tomiya, G. Wogan, B.A. Swartz, et al. 2011. Has the Earth's sixth mass extinction already arrived? Nature 471: 51-57.

Barrow, M. 2009. Nature's Ghosts: confronting extinction from the age of Jefferson to the age of ecology. Chicago University Press.

Bersaglio, B. and J. Margulies 2021. Extinctionscapes: spatializing the commodification of animal lives and afterlives in conservation landscapes. Social \& Cultural Geography. https://doi.org/10.1080/14649365.2021.1876910

Biermann, F. 2021. The future of 'environmental' policy in the Anthropocene: time for a paradigm shift. Environmental Politics 30(1-2): 61-80. https://doi.org/10.1080/09644016.2020.1846958

Biggs, D., R. Biggs, V. Dakos, R. J. Scholes, and M. Schoon. 2011. Are we entering an era of concatenated global crises? Ecology and Society 16(2): 27. http://www.ecologyandsociety.org/vol16/iss2/art27/

Büscher, B., 2021 Between overstocking and extinction: conservation and the intensification of uneven wildlife geographies in Africa. Journal of Political Ecology 28(1): 760-781. https://doi.org/10.2458/jpe.2956

Büscher, B. 2022. The nonhuman turn: critical reflections on alienation, entanglement and nature under capitalism. Dialogues in Human Geography in press.

Büscher, B. and R. Fletcher. 2018. Under pressure: conceptualising political ecologies of "Green Wars." Conservation and Society 16(2): 105-113.

Büscher, B. and M. Ramutsindela. 2016. Green violence: rhino poaching and the war to save Southern Africa's Peace Parks. African Affairs 115(458): 1-22.

Bryant. R. (ed.). 2015. The international handbook of political ecology. Edward Elgar.

Cavanagh, C. 2018. Political ecologies of Biopower: diversity, debates, and new frontiers of inquiry. Journal of Political Ecology 25: 402-425. https://doi.org/10.2458/v25i1.23047

Ceballos G., P. Ehrlich, A. Barnosky, A. García, R. Pringle and T. Palmer. 2015. Accelerated modern human-induced species losses: entering the sixth mass extinction. Science Advances 1, 5.

Dawson, A. 2016. Extinction: a radical history. OR Books.

Deutsch, S. 2021. Populist authoritarian neoliberalism in Brazil: making sense of Bolsonaro's anti-environment agenda. Journal of Political Ecology 28(1): 823-844. https://doi.org/10.2458/jpe.2994

Duffy, R., F. St John, B. Büscher and D. Brockington. 2015. The militarization of anti-poaching: undermining long term goals. Environmental Conservation 42(4), 345-348.

Duffy, R., F. Massé, E. Smidt, E. Marijnen, B. Büscher, J. Verweijen, M. Ramutsindela, T. Simlai, L. Joanny and E. Lunstrum. 2019. Why we must question the militarisation of conservation. Biological Conservation 232: 66-73.

Extinction Rebellion. 2019. This is not a drill: an Extinction Rebellion handbook. Penguin.

Hannah, M. 2021. Extinctions: living and dying in the margin of error. Cambridge University Press.

Harcourt, W. and I. Nelson (eds.). 2015. Practicing feminist political ecologies: moving beyond the 'green economy. Zed.

Garlick, B. and K. Symons. 2020. Geographies of extinction: exploring the spatiotemporal relations of species death. Environmental Humanities 12(1): 296-320. https://doi.org/10.1215/22011919-8142374

Greenberg, J. B. \& Park, T. K., 1994. Political Ecology. Journal of Political Ecology 1(1): 1-12. https://doi.org/10.2458/v1i1.21154

Guasco, A. 2020. 'As dead as a dodo': Extinction narratives and multispecies justice in the museum. Environment and Planning E 4(3): 1055-1076. https://doi.org/10.1177\%2F2514848620945310

Intergovernmental Science-Policy Platform on Biodiversity and Ecosystem Services (IPBES). 2019. Global assessment report on biodiversity and ecosystem services. IPBES.

IPBES-IPCC. 2021. Biodiversity and climate change: scientific outcome. IPBES-IPCC.

Kiggell, T. 2021. Monitoring extinction: defaunation, technology and the biopolitics of conservation in the Atlantic Forest, Brazil. Journal of Political Ecology 28(1): 845-863. https://doi.org/10.2458/jpe.3044

Koot, S. 2021. Enjoying extinction: philanthrocapitalism, jouissance, and 'excessive environmentourism' in the South African rhino poaching crisis. Journal of Political Ecology 28(1): 804-822. https://doi.org/10.2458/jpe.2984

Le Billon, P. 2021. Crisis conservation and green extraction: biodiversity offsets as spaces of double exception. Journal of Political Ecology 28(1: 854-888. https://doi.org/10.2458/jpe.2991 
LeBillon, P. and R. Duffy. 2018. Conflict ecologies: connecting political ecology and peace and conflict studies. Journal of Political Ecology 25(1): 239-260. https://doi.org/10.2458/v25i1.22704

Lunstrum, E. 2014. Green Militarization: anti-poaching efforts and the spatial contours of Kruger National Park. Annals of the American Association of Geographers 104(4): 816-832. https://doi.org/10.1080/00045608.2014.912545

Malm, A. \& Zetkin Collective. 2021. White Skin, Black Fuel: on the danger of fossil fascism. Verso.

Marijnen, E. and J. Verweijen. 2016. Selling green militarization: The discursive (re)production of militarized conservation in the Virunga National Park, Democratic Republic of the Congo. Geoforum 75: 274-285.

Martin, H. M. \& O. Pedraza. 2021. Extinction in transition: coca, coal, and the production of enmity in Colombia's postpeace accords environment. Journal of Political Ecology 28(1): 721-740. https://doi.org/10.2458/jpe.4780

Mbembe, A. 2019. Necropolitics. Duke University Press.

McCorristine, S. and W.M. Adams. 2020. Ghost species: spectral geographies of biodiversity conservation. Cultural Geographies 27(1): 101-115. https://doi.org/10.1177\%2F1474474019871645

McBrien, J. 2016. Acumulating extinction: planetary catastrophism in the Necrocene. In J. Moore (ed.) Anthropocene or Capitalocene? Nature, history, and the crisis of capitalism. PM Press, pp.116-137.

Muradian, R., M. Walter and J. Martinez-Alier. 2012. Hegemonic transitions and global shifts in social metabolism: implications for resource-rich countries. Introduction to the special section. Global Environmental Change 22(3): 559-567.

Neimark, B, J. Childs, A. Nightingale, C.J. Cavanagh, S. Sullivan, T.R. Benjaminsen, S.P.J. Batterbury, S. Koot and W. Harcourt. 2019. Speaking power to "post-truth": critical political ecology and the new authoritarianism. Annals of the American Association of Geographers 109(2): 613-623.

Nel, A. 2021. Biodiversity Economy and conservation territorialization: a pyrrhic strategy in Kwazulu-Natal. Journal of Political Ecology 28(1): 741-759. https://doi.org/10.2458/jpe.4744

Powell, M.A. 2016. Vanishing America: species extinction, racial peril, and the origins of conservation. Harvard University Press.

Ramutsindela, M., F. Matose and T. Mushonga (eds.). 2022. The violence of conservation in Africa: state, militarization and alternatives. Edward Elgar.

Rose, D., T. van Dooren and M. Chrulew (eds.). 2017. Extinction studies: stories of time, death, and generations. Columbia University Press.

Salazar Parreñas, J. 2018. Decolonizing extinction. The work of care in Orangutan rehabilitation. Duke University Press.

Schmidt, J. 2021. Glacial deaths, Geologic extinctions. Environmental Humanities 13(2): 281-300. https://doi.org/10.1215/22011919-9320156

Sepkoski, D. 2020. Catastrophic thinking: extinction and the value of diversity from Darwin to the Anthropocene. Chicago University Press.

Sodikoff, G. (ed.). 2012. The anthropology of extinction: essays on culture and species death. Indiana University Press.

Svarstad, H., T. Benjaminsen and R. Overå. 2018. Power theories in political ecology. Journal of Political Ecology 25: 350-363. https://doi.org/10.2458/v25i1.23044

Thakholi, L. 2021. The biopolitics of private conservation: jeopardizing labor and rhino to optimize capital? Journal of Political Ecology 28(1), 705-720. https://doi.org/10.2458/jpe.4764

Theriault, N., T. Leduc, A. Mitchell, J. Rubis and N. Jacobs Gaehowako. 2020. Living protocols: remaking worlds in the face of extinction. Social \& Cultural Geography 21(7): 893-908.

Tucker, M. et al. (2018). Moving in the Anthropocene: Global Reductions in Terrestrial Mammalian Movements. Science 359: 466-469.

Turnhout, E. and A. Purvis. 2021. Biodiversity and species extinction: categorisation, calculation, and communication. Griffith Law Review 29(4): 669-685. https://doi.org/10.1080/10383441.2020.1925204

Watson, D.M. and R.A. Davis. 2017. Hopeful monsters - In defense of quests to rediscover Long-lost species. Conservation Letters 10(4): 382-383. https://doi.org/10.1111/conl.12386

Wrigley, C.A. 2021. Ice and Ivory: the cryopolitics of mammoth de-extinction. Journal of Political Ecology 28(1): 782803. https://doi.org/10.2458/jpe.3030 